\title{
Study of Contra-Scripture and Tradition Condition in Marriage
}

\author{
Sahar Adel ${ }^{1} \&$ Attaollah Esmaeeli $^{1}$ \\ ${ }^{1}$ Azad Islamic University, Rasht Branch, Iran \\ Correspondence: Sahar Adel, Azad Islamic University, Rasht Branch, Iran. E-mail: niloo.group@yahoo.com
}

Received: March 6, 2016 Accepted: May 15, 2016 Online Published: November 30, 2016

doi:10.5539/jpl.v9n10p47 URL: http://dx.doi.org/10.5539/jpl.v9n10p47

\begin{abstract}
The stipulation of marriage, that is commitment and obligation, meaning that each party to the contract are entitled to ask from the other party, a specific description, act or omission, or the result of another contract, or to get committed for the benefit of the other party. About the stipulation of marriage, it can be said that it is not true that people are entitled to sign a stipulation without any criterion, and then call it "be enforceable", rather the stipulation must be signed under the terms established by law and sacred religious of Islam. The stipulations of marriage must not be against the scripture and tradition. The majority of jurists of Imamiyeh religious, according to the Hadith "Believers should fulfill their conditions, unless these conditions turn a lawful issue into an unlawful one or an unlawful issue into a lawful one " believe that the principle is the fulfillment of any stipulation, unless it is a condition which turns a lawful issue into an unlawful one or an unlawful issue into a lawful one. The contra-scripture and tradition conditions are of those unlawful stipulations, as to not damage the marriage the main pillars; they do not cause the nullity of marriage. But if they damage the main pillars of marriage, not only the stipulation has been nullified, but the marriage itself is nullified as well. This paper scrutinizes the situation of contra-scripture and tradition, and the touchstone to distinguish such conditions, as well as to investigate the extent they influence marriage.
\end{abstract}

Keywords: condition, marriage stipulation, nullified condition, contra-scripture and tradition, marriage

\section{Introduction}

Family is identified to be the central core of every society and the first society people step in and learn the customs of life and social rules and practices. Family law is the most significant part of civil rights, which does not have a mere legal aspect, rather is combined with social, moral and religious issues, and most of its rules are about public order and morality. Hence, it is necessary to review the issues regarding family formation and legal relationship between women and men. Historically, the issue of family protection and its durability and stability had always been a subject of great importance. According to Iranian civil code, marriage is considered to be a legal contract by which different rights and obligations are proved for women and men. Indeed, it is the agreement of wills to form marital relationship. As one of the law schools, Islam introduces appropriate solutions and is successful to support the rights of both parties and marriage stability. Among these strategies are the conditions that are proposed in the marriage, which gives the parties permission and freedom to pose some conditions in order to achieve their goals and desires.

Marriage stipulation is a commitment which is set in another contract, and it causes affiliation and relationship between the two parties, that the condition turns into consequential commitment. Undoubtedly, the purpose of marriage stipulation is to develop a link between the condition and the marriage itself. Similar to the marriage, the condition is a legal act as well, therefore, its authenticity and validity is subject to the fulfillment of private and public conditions, hence, the stipulations set by both parties should be according to these conditions. Therefore, if a stipulation to be in contrast with these conditions, would not be valid, and even may nullify the marriage. One of the private conditions regarding the marriage stipulation is its accordance with the Scripture and tradition, which has been considered by many Jurists.

The present time, is the time to fulfill complex contracts, and to apply different tricks to achieve advantages and privileges. Marriage is one of those contracts which contains of some stipulations, and therefore, requires more attention from both parties when either getting married or setting some stipulations.

No one is entitled to set stipulations in the marriage without any criterion, and then call it enforceable, rather the condition should under criterion of law and Islam. Stipulations should not be against the Scripture and tradition. 
The majority of Jurists of Imamiyeh religious, according to the Hadith, "The believers should fulfill their conditions, unless these conditions turn a lawful issue into an unlawful one or an unlawful issue into a lawful one " believe that the principle is the fulfillment of any stipulation, unless it is a condition which turns a lawful issue into an unlawful one or an unlawful issue into a lawful one. A contra-Scripture and tradition condition can play an important role both in marriage and in its dissolution, and also can cause a huge alteration and transformation.

Regarding the point that similar to marriage condition is identified as a legal act, therefore its authenticity and validity is a subject of fulfillment of private and public conditions. In other words, imposing the condition in the marriage, is subject to specific rules that causes these stipulations not to be beyond the rules and principles of the marriage, therefore, if a stipulation to be in contrast with this imposing, is not effective and valid enough, and even may nullify the marriage. The discussion of stipulation and its accordance with the Scripture and tradition as one of the private condition has long been considered by Jurists. The main point which can be posed here is the concept of contra-scripture and tradition stipulation in marriage and its effect on the marriage, and according to this, the present paper reviews the contra-scripture and tradition stipulation in marriage, and tries to express the reason or reasons of these oppositions to Scripture and tradition by referring to Jurists and legal opinions, and hence, answering the questions below is considered to be the basis of this study:

1) Is the criterion of authenticity of stipulation in marriage its accordance with Scripture and tradition, or lack of opposition?

2) What are the verdicts and effects of contra-Scripture and tradition stipulations in marriage?

\section{Concept of Condition}

\subsection{The Literal Concept}

In Persian the word "condition" has several meanings, such as covenant and suspending of something to something else, or to associate a word or an act with something, etc (Dehkhoda, 1998: p.14216). The word "condition" comes from "on the conditional condition" which means something that is obligatory and mandatory to someone (Noraghi, 1995: p.127).

\subsection{Colloquial Concept}

\subsubsection{In Jurisprudence}

A marriage in which there is a condition, such as someone has sold his house to someone else, and meanwhile he is pledged to present a certain book to him, here there is two deferent commitments that will differ in terms of style and form, but are the same in nature and essence; contrary to a marriage that subject of deal is a certain object from outside, to be subject of a description, because it is a single commitment for two subject.

Although this stipulation seems to be out of marriage commitment, but it is fully interrelated with the marriage, and the effect of this relationship is that the required marriage would be permitted without fulfillment of the condition, and its secret is that the necessity of the marriage depends on the fulfillment of the conditions, and if they are not fulfilled, only its necessity would be nullified, and not its essence and nature. In fact, the reference of this commitment is the suspension of the necessity of the marriage, and also the fulfillment of the condition, the evidences requirements of the conditions would be obligatory the necessity of this qualification and the necessity of its fulfillment.

Then, if a party whom the condition is against them, abstains from fulfilling a stipulation, or has an excuse, the other party that the condition is in his favor of is titled to terminate the contract (Sajadi, 1994, Vol. 1, p: 1525).

\subsection{Types of Condition}

Conditions have been divided into various types of validity:

In terms of the effect of contract referred to as three groups of suspended, contract cancellation and commitment.

In terms of the manner to express the determination, to explicit and implicit.

In terms of the method of how relate with the marriage, contract and beyond.

In terms of condition's influence, correct or void.

The division of the condition based on validity of subject which is three types:

First: the condition of qualification which refers to the quality and quantity of the subject of transaction.

Second: condition of subsequent events (condition of corollary), which is a commitment to a condition to achieve something outside the condition that if the fulfillment of the subsequent events is not conditioned to specific appurtenance and procedures, as soon as it is declined, the outcome is achieved outside the condition. 


\subsection{Third}

Condition about performance of an act, whether the act or omission, in fact, the real and prevalent concept of stipulation is this third type of act condition, and that is the sort of condition whereby one party or both are committed to complement it (Mahdavi Kani, 2000, p: 21).

\section{Concept of Scripture}

\subsection{Literal Concept}

Scripture- a written, written volumes of printed papers, scriptures as plural form, the plural form of scribe (Amid, 1984, 836). The word scripture comes from scribe, which means a person who copies out documents, especially one employed to do this before printing was invented. The word scripture sometimes refers to its infinitive form (to write), and sometimes refers to its past participle form (written).

\subsection{Colloquial Concept}

The purpose of scripture is the Holy Quran which is the total verses from Allah to the prophet of Islam (peace be upon him), as the prophet ordered, the Companions had collected them to the existing arrangement.

\section{Concept of Tradition}

\subsection{Literal Concept}

Tradition bears different meanings, such as way, method and doctrine, morality, law, its plural form is traditions (Isfahani, 2004: 265). Philologists have considered various meanings for the word "tradition", some are as follow:

1) Continuity: According to this definition, the word "tradition" means "to continue".

2) Admirable way: According to this definition, where the word "tradion" is used absolutely or along with the adverb "good", means pleasant way and style and in order to play the role of a wrong and indecent method, it should be bound to the adverb of vice (Jorjani, 1985: 53).

3) Method: According to this definition, the method people follow and are acclimatize to be called tradition (good or indecent).

\subsection{Colloquial Concept}

In colloquial term, tradition has different meanings such as:

1) Tradition in the first centuries of Sunni narrators, means the effects of Holy prophet (peace be upon him) and companions and followers (Hadith Sciences and its term: 10, Sobhi Saleh $18^{\text {th }}$ floor, Beirut, Dara al Elmo al Olamain, $1991 \mathrm{M}$ ).

And since the time of Imam Shafi'i, it refers to the act and word of the presentation of the Prophet (peace be upon him).

2) Other meanings of tradition are opposite of innovation, and the purpose of this tradition is the act which is in accordance with the master of Sharia (Deraye Al Nafis, p: 37, Nafisi, 2013).

3) Sometimes tradition refers to act of companions' in the books of companions of Hadith (Zamanian, 2007: 18).

4) Tradition means permanent commonplace facts or eternal wisdom.

In this study tradition means the words, actions, and statements of the Prophet and the Imams (peace be upon them).

\subsection{The Concept of Marriage}

The word "marriage" is the noun form of the verb "marry" (Mohaghegh Damad, 1986: 21). In legal literature of Persian, the word "espousal" is being used side by side with marriage (Katouzian, 1992). The importance of definition of marriage is laid in opening doors to identify the truth of marriage itself. The marriage is: "The accordance of two wills to develop a conjugal relationship". This definition is general and includes permanent and temporary marriage.

\subsubsection{In Jurisprudence}

Sheikh Toosi, knows the marriage as contract in Islamic Sharia (Sheikh Toosi, 1992: 280). Bojnordi, defines marriage as the commitment of woman to be the wife of a man in the world of validity (Mousavi Bojnordi, 1991: 280). Of course the application of the term "commitment" in jurisprudence, plays the role of its legal meaning and includes such issues such as property and marriage, as well as what the committed party should perform (Dadmarzi, 
2000:77-79). The majority of jurists take marriage as its literal meaning "contract", (whether in its meaning of cause or reason) and not intercourse. Although emphasizing on the recent meaning seems not to be fruitless. For example, if we take the condition of "pregnancy from marriage" in the distribution of Rida respect as the "pregnancy from sexual intercourse", if a woman becomes pregnant without intercourse with her husband, her milk does not distribute respect (Shobeiri Zanjani, 1998: 8). A contemporary jurist, introduces the equal ratio of parity which is being husband and the holy Quran applies it for both men and woman, as the builder of the reality of marriage, not builder of authority (Makarem Shirazi, 2003: 93-94).

\subsubsection{In Legal}

Espousal or marriage does not have a specific definition in Iranian civil code, and perhaps because it is evident, the law maker feels no requirement to make a clear definition. But perhaps the diversity of the effects and outcomes of marriage and missing of its pillars and core elements contributes to the problem. Some of legal experts define marriage this way:

"Marriage is a legal relationship which is being established by contract, making them entitled to take the sexual advantage of each other" (Mohaghegh Damad, 1986: 22).

\section{The Necessity to Fulfill the Condition}

The importance and necessity to fulfill the condition can be inferred from different verses and hadiths:

\subsection{Verses}

In Holy Quran, the word "condition" has not come in singular form, just once in plural form "conditions" as to add to pronoun, referring to the resurrection. "Now, there are its signs", (Muhammad: 18). The verse: "O Isaiah, remember the blessing I bestowed upon you, and fulfill your covenants (conditions), so that I fulfill my promise, and only fear me" (Baqarah: 40). This verse is addressed to the sons of Jacob. The verse "O believers, fulfill your covenants (conditions)", (Maeda: 1). It is said that, the expression "fulfill your covenants" and so forth, the necessity of fulfillment depends on desired requirements. If there is necessity and obligation on the way of requisiteness, such as sale and rental and if not, to the way of license such as company and mudaraba, and the purpose is not that every contract must be fulfilled (Mirzaye Qomi, 1992: 41).

About referring to the general evidence of contract fulfillment, it should be known that the contract is either correct or nullified; and apparently the obligation of fulfillment is consequential to the correct contract, consequently, inevitably in the first place the type of contract that whether it is correct or nullified should be investigated, then the obligation of its fulfillment should be surveyed. The verse of: "Do not approach the orphan`s property except in the best manner, till they are matured, and fulfill your covenants (conditions), truly it would be questioned about covenants (conditions)".

The purpose is the covenant with God to perform your obligations, and also what you promised to perform. The implication of necessity of covenant fulfillment from this verse is inferred by two dimensions: first, the manner of expression is imperative, and second, the one who promises is responsible and would be questioned in the day of resurrection.

Hence, the responsibility of committed to fulfill the covenant (condition) means the obligation of its fulfillment. Fulfillment of a covenant is so important that according to the verse 76 of Surrah Al-e-Omran: "Those who fulfill their promises are pious and beloved by God".

\subsection{Narrations}

Ayashi interpretation mentions from Ibn Sinan who said I asked from Imam Hussein, what is the purpose of God when said "O believers, fulfill your covenants"? Imam Hussein replied: covenants means promises, hence the order "fulfill" implies obligation. Also there is citation from prophet of Islam (peace be upon him) who said: "Muslims fulfill their covenants and conditions". Here the words of infallible imply the necessity to fulfill the covenant.

The necessity to fulfill the covenant is to that extent that Imam Ali in his decree to Malek Ashtar says:

$<\ldots$ If you make a pact with your enemy and give him a garment of peace, never break your promise, in the issue of asylum observe everything, make yourself a shield to protect your covenant, because despite the diversity of people's views and ideas, nothing is more necessary and vital than covenant fulfillment in Islam. Even before the advent of Islam, since the idolaters were aware of the outcome of abjuration, remained determined to fulfill their covenants..." (Moghimi, 1980: 1051).

Imam Sadeq (peace be upon him) said: “ Believers (Muslims) should fulfill their covenants (conditions), unless 
these conditions turn a lawful issue into an unlawful one or an unlawful issue into a lawful one ". Although the expression "believers" is predicative, but in fact it is a verdict composition, and the purpose of a predicative sentence is not to inform, rather the goal is to discuss and to express the desirability of the sentence (Mohaghegh Damad 2: 39 rules of fiqh).

\section{Types of Conditions}

Conditions have been divided based on different validities.

\section{Types of Conditions Based on being Interrelated and non Interrelated with the contract}

The purpose of preliminary condition is the condition which is not mentioned in stipulation, rather it is provided independently and out of a particular and specific contract between two parties. Mr. Dr. Jafari Langaroudi affirms about preliminary conditions: The purpose is the commitment of a party, and that is a necessary commitment that an individual provides against himself in favor of the other party (Jafari Langaroudi, 1988: No. 3044). According to the views of jurists, the preliminary condition is nullified.

Regarding the aforementioned, in preliminary condition, only one party is committed in favor of the other party, without any obligation from the other party for it. It is clear that the acceptance of the other party does not evict the commitment from being a preliminary condition. In jurisprudence, according to the most of jurists, independent commitments such as someone says: I am committed to pay one million Toman to you, or to perform a particular activity, or give it up, are considered as preliminary conditions, and does not bring obligation about the individual (Tabatabaee Yazdi, 1999: 219).

\subsection{Masonry Condition}

Masonry condition, collusion condition, implicit condition, conditions terms of contract

Masonry condition is the commitments which are discussed between parties in preliminary negotiations that are not mentioned in the contract. The definition of such condition is: "negotiations of the parties before contract and to make an agreement and therefore, do not reiterate them while signing the contract, which is called masonry condition and collusion condition" (Jafari Langaroudi, 1976: 228).

It seems that the masonry condition should be divided into two categories due to the obligatory:

One category is those of customary appurtenances of contract or usually the contract is conditioned on them, in this way, although they are not stipulated in the contract, still are necessary to fulfill. Hence, it is said that affairs such as submission and surrender and the price to be realizable due to its obligation before usage and habit are the implicit implications of the contract, and not only there is no need them to be stipulated in the contract, but also if the parties are not aware of the obligatory of such affaires, still they are required to fulfill them.

The other category, are those which are not the same as what mentioned, and therefore to emphasize on their fulfillment obligation, they should be stipulated in the contract, that in recent category, regarding the point that they are "stipulations" are identified to be necessary to fulfill, not because they are colluded before the contract. Because the condition which is not stipulated in the contract is not necessary to fulfill, and the general concept of "Believers should fulfill their conditions) is not about the independent commitments and irrelevant to the contract, and accordingly the extent of certainty of "Believers should fulfill their conditions" is the stipulation, for this reason the majority of jurists consider the preliminary obligations and unrealistic commitments based on expertise and specialty out of the aforementioned principle (Bojnordi, 1992: 252).

\subsubsection{The Status of "Masonry Condition" in Iranian Civil Rights}

The Iranian Civil Rights has accepted the "masonry condition", but gives no definition of it. Lawyers often mention a meaning which is congruent with "the stipulation before the contract "when analyzing the legal provisions regarding the application of law, with the stated definition, although they consider "masonry condition" as one type of "implicit condition".

The civil code in articles 1113 and 1128 of the book "marriage and divorce" explicitly recognizes the "implicit condition" as legal, according to the article 1113: "in a temporary marriage, the woman is not entitled to receive alimony, unless it is stipulated, or the contract is signed based on it." Article 1128 cites: "if a specific qualification is stipulated for one party and after marriage it reveals that the mentioned party does not enjoy intended qualification,

the other party is entitled to nullify the contract, whether aforementioned qualification is stipulated in the contract, or the contract is collusively stipulated on it". Obviously there is no intimacy for marriage contract that we know the legitimacy of "masonry condition" limited to the articles provided in the law, on the contrary, if the 
marriage, regarding its religious importance, implicit masonry condition is legitimate, a fortiori would be valid in other cases as well.

\subsection{Stipulations}

The conditions which are stipulated in the contract are called stipulations. As mentioned before, a stipulation should be necessarily expressed in the context of contract, or be cited, so that implications to its agreement would be taken as its affirmation, such as referring to a clear condition which had been agreed earlier. Hence, earlier negotiations are not sufficient, because the parties may have negotiate on various affairs before the contract, and its commitment and acceptance of its future works exist if it is specified when signing the contracting, otherwise no works could be built on it. What is out of the framework of the contract cannot be known as its function in terms of obligation, unless it is stipulated in the contract and acquires obligation from it. Hence, there is no doubt in the necessity of stipulation and invalidity of the condition which is not stipulated in the contract.

Some of legal experts in defining "stipulations" have cited: "any condition which is established in favor of one party or against the other party is called stipulation, even if negotiation about the condition has been done before the contract, and the contract is signed based on previous negotiations (Jafari Langaroudi, 1988: 383).

Stipulation is an obligation in another obligation, so that the contract (or the main obligation) remains as a source of obligation for the condition, so the condition acquires obligation from it, and makes it possible that "the party that the condition is against him/her" to adhere such commitment. The purpose of source of obligation of something is the place or event which creates it, accordingly if the condition is stipulated in the contract, its obligation would be a contractual obligation, based on which "the party that the condition is against him/her" is pledged to fulfill what is conditioned.

According to Imamiyeh religious jurists, the principle is that any type of condition is correct and applicatory. On other words, in Imamiyeh religious jurisprudence "principle of freedom of conditions" such as principle of freedom of contracts is of established legal principles in contemporary law. The requirement of the mentioned principle is if some issues of the stipulation are considered as incorrect, are exceptions on principle and require a special justification (Allameh, 2008: 36).

The condition should be stipulated in the contract, so that it would possible to specify its validity or corruption. However some of jurists consider the agreements acquired before and after contract amongst the category of stipulations as well (Katoozian, 1990: 169). There is a quotation from Allama Helli that: "any type of condition which is stipulated in the contract is necessary to be fulfilled (Mohaghegh Damad, 2009: 205).

\subsection{Types of Condition in Terms of Its Influence}

Correct Condition: The purpose is the condition that is permissible to stipulate, and is necessary to fulfill. The works of a correct condition is to affirm the right for "the party that the condition is in favor of him/her", and makes "the party that the condition is against him/her" committed to fulfill it.

Nullified Condition: "Nullifies" literally means vain and ineffectual (Amid, 1984: 239). "Nullified condition" means vain and corrupted obligation that all evidences does not include its fulfillment and "the party that the condition is against him/her" is not required to fulfill it, also it is not supported by the law. Conventionally the obligation of "the party that the condition is against him/her" to fulfill a nullified condition is something absurd and unacceptable (Jafari Langaroudi, 1988: 384).

There are two types of nullified conditions, some would corrupt the contract, and some do not.

\section{Contrary Condition to the Requirements of the Contract}

Any contract as soon as fulfillment would cause some works and requirements. These are called the requirements of the contract.

Works and requirements of the contract can be divided into two categories:

\subsection{Requirements of the Nature of the Contract}

Requirements of the nature of the contract can be defined as:

The requirement of the nature of the contract is the purpose, for which the contract is signed, and in case of missing that purpose, the parties would not sign the contract. If the main purpose is not achieved, it means that the contract has deviated from the intention. On the other hand, we know that any contract leads to achieve a work which is required per se, so that the fulfillment of the contract would be impossible without its achievement. The particular works and purpose of the contract cannot be misdeed condition. It means that the contract 
contrary to what it requires per se, and the works of the main pillar and main consequences of the contract are corrupted, because misdeed condition means the corruption of the main pillar and is opposed to the fulfillment of the contract, as if to sell something to the condition that the buyer would not own it. In this case, there is the opposition between the two obligations, contract obligation and condition obligation. Because the content of the first is ownership and the latter is denial of ownership (Shahabi, 1954: 53).

Thus, wherever the condition is inconsistence with the requirements of the nature of the contract and there is a conflict between them, the contract is nullified. Such as the opposition to the contract to the transfer of "exchange of one for another" in commutative contracts, or transfer of the right to obligation of drawee in assignment contracts, or acquiring bond of matrimony in marriage which are the requirements of the nature of the contract.

What nullifies the contract is the condition contrary to the requirements of the nature of the contract, not the condition contrary to the requirements of the works of contract. Such as: when selling an object, there is a condition that the buyer is not entitled to transfer the object of sale to a third party, both the contract and condition would be correct and valid, because this condition is opposed to the works of obligation of the contract, and not to the obligation of the nature of the contract itself (Shahidi, 2004: 87).

However, in any case that nullification of a condition damages one pillar of the contract, may lead to the contract nullification, the contrary condition to the requirements of the nature of the contract is one of the issues that believers on detailed between nullified conditions and nullifiers know it the corruptor of the contract.

\subsection{Requirement of Application of Contract}

Requirement of application of contract are the affairs that when the contract occurs in an application manner and without any conditions, that affairs are expedient, they are not the requirement of the nature of the contract, rather than the contract which has been realized in an application manner, are established subordinately, unless they are stipulated and emphasized in the contract, and the common purpose of both parties implicates its necessity. The important point of lacking necessity of such works is due to the misdeed condition in the contract. The parties may stipulate the affairs which are contrary to the obligations of the application contract, or limit some of its works partially. For instance, since the main purpose of transferring a property is absolute possessions, then if lack of it or lack of some in general is conditioned, this condition may be inconsistent with the requirements of the nature of the contract, but not enjoyment of the sales could be conditioned for a certain period of time.

Iranian civil code has recommended such conditions. Article 281 of civil code "The expenditures of the reimbursement in case of lacking of any stipulation against it, meaning that the application requirement of the contract necessitates would be for the debtor, but the parties may condition against it, and if there is such condition, such condition would not nullify the contract, but would be valid and imperative for the parties as well". Also article 280 of civil code "the place of fulfillment of an obligation should be where the contract has been signed, unless there is a particular contract between the parties, or usage requires somehow differently". The recent mentioned article declares another case of the condition of contrary to the requirements of application contract. Accordingly, not only the condition of contrary to requirements of application or works and separable appurtenances of the contract is permissible, but also "the party that the condition is against him/her" may be committed to fulfill it (Allameh, 2008: 164).

\subsection{Concept of Contra-Scripture and Tradition Conditio}

The most significant valid affair in veracity of a condition as one of the specific stipulations is its consistency with the Scripture and tradition, and the parties are not entitled to accept a contra-Scripture and tradition condition. The reason of such condition is that no affair should be opposed to the Scripture and tradition, and marriage stipulation is of these affairs as well, and opposition of the condition to Scripture and tradition leaves no justification for its veracity.

This condition has been considered by the jurists studying the veracity of the condition and there is a consensus of opinion among them. The majority of jurists of Imamiyeh religious have discussed separately about the condition of "non-opposition to Scripture and tradition" and "permissible condition" (Noraghi, 1995: 46).

Some other jurists declare that the second condition is an actual example of the first one, and cannot be discussed separately (Fakhar Toosi, 2006: 50). But according to Sheikh Ansari, the condition of "non-opposition to Scripture and tradition" has a concept more than the "permissible condition". Hence, in the part of conditions of veracity of stipulation, it would be discussed separately.

After it is accepted that the purpose of the Scripture is all the commandments which God has recorded. 
Accordingly, there is not any contra-Scripture and tradition, unless that condition would be contrary to the Scripture, and the best statement in these narrations is the hadith from Imam: A condition which is not recorded by God (Haram Ameli, 1992: 290). In other words, it means a condition which is not according to the Scripture. It can be said that in this tradition, opposition or accordance of the Scripture has not been described, but a condition with the content of other than Scripture.

\section{What is the purpose by saying contra-Scripture and tradition stipulation?}

However, is it necessary that the condition to be in accordance with the Scripture? Or is it sufficient that the condition does not oppose to Scripture and tradition for its veracity? Late Sheikh Ansari declares: According to the stated narrations, it is necessary to be in accordance with the Scripture, and lacking of opposition to the Scripture seems not to be sufficient, but declares, it is not unlikely that the goal of accordance is lack of opposition to the Scripture.

Ayatollah Tabrizi states: "The status of obligation of being in accordance with the Scripture to the lack of opposition is that if we call the subject of accordance "a condition", mention of lack of opposition in narrations would be in vain, and it would be necessary that the declaration of this ordinance would not be in proportion with the expression of criterion and law, because the accordance of many conditions cannot be inferred from the Scripture, and if it is said that this condition is in accordance with the nature of Quran, we would reply this is not acceptable, because referring to the nature of Scripture is not in commensurate with the grant of the criterion, rather what elucidate the law are the appearances of the Scripture (Tabrizi, 1990: 388).

Sheikh Ansari declared about the reason that the conditions must be concurrent with or not opposed to the Scripture and tradition:

First: The purpose of Scripture are the ordinances from God to His servants, even though they are stated from the tongue of His prophet (peace be upon him). In other words, the purpose of Scripture is not the subject of Quran, rather is "all the ordinances to the obligated". It makes no difference that they are in Quran or Nabavi Hadiths from the prophet of Islam (peace be upon him). Then, if it is conditioned that loyalty is owned by the vender, regarding the Nabavi Hadith of "loyalty to those who set free", (this Hadith goes back to the preliminary era of Islam when slavery had not been abrogated yet), this condition should be considered as the opposition to the "What Allah has decreed for us".

Second: It can be declared that the accordance of the condition with the Scripture means it is not opposed to it. If the condition is not opposed to the legitimate, it inevitably would be in accord with the majorities and applications in the Scripture and tradition.

However, it can be declared that what causes illegitimate and nullification of the condition is opposition to the Scripture and tradition. As a result, criterions and standards are the lack of opposition (Allameh, 2008: 104).

\section{General Conditions of Validity of the Stipulation}

Sheikh Ansari mentioned eight conditions for the validity of the stipulation in his book "Makasib".

These conditions are exerted in all contracts, and can be called "the general conditions of validity of the contracts", which are as follows:

1) The condition to be possible.

2) To be permissible per se.

3) To be rationalistic.

4) Not to be opposed to the Scripture and tradition.

5) Not to be contrary to the obligations of the contract

6) Not to be an impossible necessity (distant or meeting of two contradicts).

7) To be stipulated.

\section{Types of Stipulations}

1) In most of the condition which is invalid and nullifier of the contract: Jurists say that some conditions are both invalid and nullifier of the contract, such as the parties condition that each are entitled to terminate the contract in three days, less or more. This condition according to the majority of jurists is invalid and nullifier of the contract, because is contrary to the obligations of the contract (Moghnieh, 5, p: 187). It seems that this condition is against the policies of the marriage, and is irrelevant to the requirements of the contract which is marital interest and legitimacy of enjoyment from each other. 
2) In most of the conditions which are invalid, but does not nullify the contract: An invalid condition is the one which does not enjoy one of the conditions of validity of the stipulation, for instance, spouse conditions that her husband is not entitled to marry with another woman, or never divorce her. Sheikh Ansari states in "Makasib": this condition is against the Scripture, but does not nullifies the contract, and motioned some narrations from Imam Bagher and Imam Sadegh (peace be upon them) which implicates the nullification of such conditions (Moghnieh, 3, p: 9), not to be committed to the invalid condition does not create a right to the other party.

3) In most conditions which are correct, and the lack of it would give "the party that the condition is in favor of him/her" right for post-facto rescinding, such as the spouse conditions that the wife should be virgin, then if after marriage it is revealed that she is not virgin, the husband is entitled to terminate the contract (Moghnieh, 5, p: 187).

The majority of jurists declared that its loss would give the right for post-facto rescinding to "the party that the condition is in favor of him/her" (Najafi, 30, pp: 376-377) and some declared: the loss of every legitimate condition in marriage would bring the right for post-facto rescinding (Hali, p: 636). The correct condition which is necessary that "the party that the condition is against him/her" fulfill it, but lack of commitment to it would not bring the right for post-facto rescinding in marriage; such as, the condition in which the wife is not entitled to departure from her town, or to dwell in a certain house or city. These conditions are correct, but if the spouse does not fulfill them, and wants to take his wife out of the city or to get her settled in another city or house, it would not give the right to terminate the marriage to his wife, but she could not follow her husband (Bahrani, p: 540).

\section{Some Cases of the Conditions Contrary to the Scripture and Tradition}

1) When in marriage, the second wife conditions that his property transfer to her after the marriage, this condition is invalid, because transferring property is a legal action which must be conducted under certain conditions, with the free will of the parties.

2) If the spouse asks her husband to leave the custody of their future children to her when contracting, and her husband who is their father has no right in this regard, this condition is invalid, because the father's custody of children is the ordinance of legislator, and according to lawyers is of imperative acts, and not influenced by the individual's will, basically, the father's custody of child is not a right, hence, it is neither lapsable nor transferable.

3) When the spouse conditions that his wife does not have the right of alimony and his wife accepts it, this condition is invalid. Paying alimony is the duty and obligation of the husband, and the right of the wife as well, and the wife could waive the overdue alimony, but the alimony which has not reached its due date is not lapsable. Because it is an actual example of "to waive something that has not become obligatory", and basically alimony is for obedience, and waiving it for the future is not correct. The wife is entitled to waive the alimony when she is deserved to receive it.

\section{The Opposition of the Condition to the Scripture and Tradition}

The contra-Scripture and tradition condition or the so-called "illegitimate condition" is invalid as well. Of course these conditions are divided into three types:

1) Illegal condition: The content of condition is necessary when the Islamic Law makes it obligatory, while the illegal act would never be obligatory as a primary religious statement, such as: murder of an innocent man or drinking alcohol. Although it can be obligatory as a secondary religious statement. Like drinking alcohol for life preservation. However, the title of condition does not endow the illegal act with the title of secondary, and its reverence of that act would prevent the condition to influence (Asadinejhad et al., 2011, 5).

2) The condition contrary to the ordinances and rules of God: Like that in sale contracting, it is conditioned in the manner of condition of corollary to one of the parties that his wife to be a divorcee, or a non-contracting person to be his heir. The reason of the invalidity of such conditions are the declared explicit informs, such as "the condition of Allah is prior to your conditions" (R. K. Sheikh Hor Ameli, 22: 36 Alvasayel).

3) The condition that makes an unlawful lawful and a lawful unlawful: As for it is stipulated that an unlawful act to be lawful for "the party that the condition is in favor of him/her", or a lawful act to be unlawful for him/her, the condition is invalid. 
In first category of conditions "the party that the condition is against him/her" is obligated to perform an unlawful act, but changes recent conditions of the divine ordinance, meaning that thereunder an act which is canonical unlawful changes and is permissible or unlawful.

As well as the recent conditions differ from the second category, because may the content of condition in the second category is not lawful and unlawful, and the legislator only is as of codification, like commands of inheritance which are of codification commands and not obligatory. But the reason that the third category is invalid, are the explicit narrations that refers to the lack of influence of these sorts of conditions.

About opposition to the Scripture and tradition, it is declared that the condition should not be against necessary lawful ordinance. For instance, if a party to a transaction hires someone with the condition that he should break his fast at noon in the month of Ramadan, this condition is invalid, because it opposes to something which its necessity is the religious ordinance.

\section{Conclusion}

As mentioned, marriage is identified to be a legal contract thereunder the parties enjoy some rights and obligations, and are entitled to insert some conditions in the framework of Sharia and law. Stipulation is a kind of condition which is inserted in the contract, and is agreed by the woman and man, and becomes officially valid when signed by both parties.

The main point is, the conditions inserted when contracting are subject to some certain rules and requirements. Hence, if the stipulations are in contract with these rules, they would be invalid.

One of specific characteristics of the validity of a condition is lack of opposition to the Scripture and tradition. The parties of a contract are not entitled to agree about a condition which is contrary to the Scripture and tradition. The purpose of contra-Scripture and tradition is that they become committed to an issue which is opposed to what is generally or especially approved by Scripture and tradition and contradicts to it, meaning that the condition and conditional are something contrary to what is approved by one of them. Hence, if a condition denies the validity of what is approved by the legislator, or agrees with what the legislator demonstrates the falsity of, such condition is opposed to the Scripture.

But the purpose of the Scripture in "contra-Scripture and tradition condition", as Sheikh Ansari declared is the holy Quran and contains of ordinances of the Prophet of Islam (peace be upon him) as well. Then it contains of both ordinance from Quran, and the issues stated as public and general ordinances. Because, it is clear that if the Quran commands to obey all the religious ordinances, even though they are not from Quran itself, as far as states "Receive what the prophet has brought for you, and stop what he prohibited", hence, if a condition is opposed to the Prophet of Islam, definitely would be opposed to the Quran.

Thus, it can be concluded that the aim of Scripture, are the religious commandments that God has ordained His servants. Even though it is not stated in the Quran, and declared by the prophet. Otherwise most of the conditions would be deemed as invalid due to not being mentioned in the Quran.

About the reason that the conditions must be agreed with or not opposed to the Scripture and tradition it can be stated that the purpose is the lack of condition`s opposition to the Scripture and tradition, because what is not opposed to the ordinance of God is acceptable.

As Sheikh Ansari Stated, the accordance of the condition with the Scripture means it is not opposed to it. If the condition is not opposed to the legitimate, it inevitably would be in accord with the majorities and applications in the Scripture and tradition. However, what causes illegitimate and nullification of the condition is opposition to the Scripture and tradition. It can be said about the ordinances and works of contra-Scripture and tradition that these conditions are of illegal conditions that this category of conditions is of void conditions; hence they do not damage the contract (derived from article 232 of civil code).

It can be said regarding the works and ordinances of void conditions of marriage that four theories have been stated which would be mentioned here: for instance if it is stipulated that the husband is not entitled to remarry, contemporary jurists have opined about the legal condition and established rights for "the party that the condition is in favor of him/her" as follows:

1) The condition is void and nullifier of the contract; because it is illegitimate, and in addition every void condition nullifies the contract.

2) The condition is void, but does not nullify the contract.

3) The correct condition is obligatory, but if the husband remarried, the remarry contract is not nullified. According to this theory if a stipulation whose content is abandonment of a legal act is violated, the performed 
act is not void, rather creates power to transaction, because the power to transaction cannot be conceived in marriage contract, the wife may not have the right for post-facto rescinding in case of any violation by the husband.

4) The mentioned condition is correct, and prevents from remarriage, meaning that in cases that the husband violates this condition, the remarriage contract is nullified.

There is difference of opinion among jurists over the issue that how unlawful condition influences the original contract. Some conceive the nullification of the contract, but the judgment of majority of jurists is based on its opposite. For instance, if there is a condition in a marriage contract that intercourse and divorce is within the control of woman, there only the condition is nullified, and the contract is correct. Some of jurists conceive the nullification of the contract, because the purpose is not merely the nature of the contract, rather is a set of conditions, "the contracts are subject of intentions of the parties". For instance, if it is conditioned that wife or husband do not perform their marital duties, or there may not be marital relationship between them, since such condition is in contrast with the nature of the contract, would be both nullified and nullifier of the contract. In fact, this condition reveals that there is no serious intention for marriage, and because of this the contract cannot be correct.

It must be considered that what is nullified and nullifies the contract is the condition which is contrary to the nature of the contract, and not contrary to the application of the contract. When the marriage contract is signed absolutely and without commitment to some affaires, may require some issues. For instance, a contract without the condition of place of living requires that the man is entitled to appoint the place of residence. The condition which is in contrast with these may not nullify the contract and is not subject to the article 233 of civil code, and if this kind of condition is unlawful, it is not nullified too. For instance, if it is conditioned that the woman is entitled to appoint the place of residence, this condition pursuant to the article 114 of civil code is correct.

Eventually, it can be concluded that, if a contra-Scripture and tradition condition does not damage the principles of the contract, may not nullify it, but if it damages the principles of the contract, it is both nullified and nullifier of the contract.

\section{References}

Allameh, S. (2008). nullified conditions and its effects on the contracts (2nd ed.). Nashr publications, Tehran.

Amid, H. (1984). Amid dictionary (1st ed.). Amir Kabir publications, Tehran.

Ansari, S. (1994). Makasib, volume II, journal of Etelaat, Tabriz, second edition

Asadi nejhad, S., Imanpour, A., \& Tondkar Bala Jourshari, S. (2011). the study of the contra-Scripture and tradition condition. Allameh scientific-professional quarterly, 11(35).

Bisotooni, M. (2011). the translation of Majmao al Bayan Fi Tafsir al Quran (27th ed.). Astan Qods Razavi, Qom.

Bojnordi, S. (1992). Ghavaed al Faqiha (Vol. III, 2nd ed.). Ismailian press institute, Qom.

Dadmarzi, S. (n.d.). the concept of contract in civil law. researches of human sciences, Qom.

Fakhar Toosi, J. (2006). the description of rights for post-facto rescinding (Vol. 8, 5th ed.). Morteza publications, Qom.

Hor Ameli, Sh. (1993). Vasayel al Shia (Vol. 23, 2nd ed.). Matbaa Mehr, Al al Beit al Tarath institute, Qom.

Isfahani, H. (2004). translation and research of single elements of Quran (with the interpretation from Khosravi Husseini, Gh., volume II, Maktab al Mortazavieh Leehyae Athar al Jafarieh, Tehran.

Jafari Langaroudi, M. (1988). terminology of law (4th ed.). Ganj e Danesh library, Tehran.

Katouzian, N. (1990). civil rights- public rules of contracts (Vol. 1\&5, 45th ed.). corporation of publication.

Mahdavi Kani, S. (2000). marriage stipulations. quarterly of Nedaye Sadeq, (17-18).

Makarem Shirazi, N. (2003). Kitabo al Nikah (Vol. I). publications of Imam Ali faculty, Qom.

Mirzaye Qomi, M. (1992). Jameo al Shatat, corrected by Mortaz Razavi (Vol. II, 1st ed.). Kayhan publications organization.

Mohaghegh Damad, S. (1986). the legal juridical study of family. publication of Islamic sciences, Tehran.

Mohaghegh Damad, S. (2009). public theory of conditions and obligations in Islamic rights (2nd ed.). Tehran.

Mousavi Bojnordi, S. (1991). Alqavaed al Faqiha (Vol. III, 2nd ed.). Ismailian press institute, Qom. 
Nafisi, Sh. (2013). in the mirror of hadith (2nd ed.). Samt publications.

Noraghi, M. (1996). Avaed al Ayam Fi Bayan al Ghavaed al Ahkam. publications of Islamic propagation, Qom.

Sajadi, S. (1994). the culture of teachings in Islam (3rd ed.). Tehran, Koumesh.

Shahbi, M. (1954). rules of jurisprudence (4th ed.). publications of university press.

Shahidi, M. (2004). civil rights (commitments) (Vol. III, 4th ed.). Majd publication, Tehran.

Sheikh Toosi, A. (1994). Tahzibo al Ahkam (4th ed.). Daro al Kitabo al Islamiah publications, Tehran.

Tabatabaee Yazdi, S. (1999). margin of Makasib (1st ed.). Ismailian publications, Qom.

Tabrizi, J. (1991). Ershad al Taleb (1st ed.). Ismailian press institute, Qom.

Zamanian, M. (2007). Sunni religious demonstrations (1st ed.). Adyan publications, Qom.

\section{Copyrights}

Copyright for this article is retained by the author(s), with first publication rights granted to the journal.

This is an open-access article distributed under the terms and conditions of the Creative Commons Attribution license (http://creativecommons.org/licenses/by/4.0/). 